of artificial lighting and into electronic developments has been outstanding. During the present War he has collaborated with the Armed Forces and with the Supply Departments on many matters of outstanding national importance. Dr. Paterson was elected a fellow of the Royal Society in 1942 .

\section{Honorary Member}

THE Council of the Institution of Electrical Engineers has elected Mr. John Somerville Highfield, past-president, to be an honorary member of the Institution. This distinction has been conferred upon him in appreciation of his distinguished work in the development of the science of the supply and application of electricity. Mr. Highfield became chief engineer to Stafford and St. Helens, Lancashire, after which he was appointed chief engineer and manager of the Metropolitan Electric Supply Company. As senior partner in the firm of Highfield and Roger Smith, he later acted as consulting engineer for the Central Electricity Board and several large electricity undertakings and industries in Great Britain and abroad. He also became a director of the London Power Company, the London Associated Undertakings, the Central London Electricity Ltd., etc. Mr. Highfield originated the elosed-bar system for switchgear, discovered the reason for the failure of high-voltage alternator windings, and introduced to England the Thury system of high-voltage D.c. constant-current generation and distribution. During the War of 1914-18 he demonstrated at sea the use of shrouded hydroplanes for submarine detection.

\section{Engineering and the Future}

Mr. Frank Parfett delivered his second presidential address before the Society of Engineers on February 5. He stated that there is a widespread and growing opinion among professional engineers in favour of federation of their institutions in order to have co-ordination of policy and joint representation on matters which are common to the whole profession. During the past year, two committees, the members of which came from various institutions, have been concerned with this matter, one of them dealing with national and the other with international federation. Very shortly proposals will be circulated to the councils of the bodies concerned for their consideration. Referring to the possibility of conscription after the War, Mr. Parfett said that the problem for peace-loving nations when war comes is to be ready and active with the minimum time-lag. The training of engineering personnel must therefore not be wasted. Young engineers in the future who are required to have army training should be sent to military engineering centres, and at the end of their term they should be entered on the National Register according to the sphere in which they could best serve the country in a national emergency. Factories, means of production, and personnel should be so organized that in the event of war we can immediately change from peace production to war production. Among post-war improvements suggested by $\mathrm{Mr}$. Parfett was that of road and street lighting. $\mathrm{He}_{e}$ believes that main and secondary roads throughout Britain should be so illuminated that individual lighting on road vehicles would be unnecessary and merely reserved for minor roads. In all general utility articles, the public should accommodate itself to the acceptance of mass-produced articles from standardized designs. This would allow methods of production to be improved, which is the only way in which industry will be able to meet the higher wages now being demanded. Mass production does not mean the death of individual craftsmanship, for which there is still ample scope.

\section{Conference on Science in War}

THE Association of Scientific Workers is holding a Conference on "Science in Peace" on February 17-18 at the Caxton Hall, Westminster. The Conference is being organized in three sessions. The first, on Saturday afternoon, will deal with ways of securing an expanding economy and full employment. The problems of the effects of science on the productivity of labour will be introduced by a member of the Amalgamated Engineering Union, and specialists in each field will discuss in detail how science can be used to develop the basic British industries. The second session will deal with the more internal problems of science. The needs of fundamental research, and of applied science and technology will be dealt with, and papers will be read on the training of scientific workers, the organization and finance of science and information services. The third session. will deal with the way in which science can affect the everyday life of each individual. The topics to be covered are research into consumer needs, health, food and agriculture, building and homes, and the place of science in culture. Tickets for the Conference (5s. for the three sessions, $2 s .6 d$. per session) and further information can be obtained from Mrs. B. Ryerson, Association of Scientific Workers, Hanover House, High Holborn, W.C.1.

\section{Announcements}

Dr. Harlow Shapley, director of Harvard College Observatory, has been re-elected to the presidency of the Society of Sigma Xi, the American society for the encouragement of research in science. Dr. Frank B. Jewett, president of the National Academy of Sciences, has been elected member of the Society's national executive committee and Dr. M. C. K Jones, of the Esso Research Laboratories, Elizabeth, N.J., is to be a new member of the national membership committee.

Dr. B. A. Keen, scientific adviser to the Middle East Supply Centre, has completed a second extensive tour of Middle East territories. He has now returned to England for further consultations, and the completion of his report on the problems of agricultural and rural development in that area.

DR. J. P. LAWRIE, senior press censor, Scientific and Technical Censorship, Ministry of Information, has, after five years service, resigned his appointment in order to take up new duties with the Royal Naval Scientific Service.

DR. HENRY DE LASZLo, managing director of L. Light and Co., Ltd., Old Bowry Laboratories, Wraysbury, fine chemical manufacturers, is visiting the United States, Mexico, Portugal and Spain. He will be making a survey of sources of organic intermediate chemicals manufactured in the United States, arranging for contracts for future delivery, and purchasing out of the way organic research chemicals not manufactured in Great Britain. Research workers and others requiring any particular substance are invited to communicate with Messrs. Light. 